\title{
Performance of a pyramid solar still with stepped trays: Experimental approach
}

\author{
A.I. Bakry ${ }^{a}$, Y.A.F. El-Samadony ${ }^{a, b}$, , H.M. El-Gohari ${ }^{c}$ and M. Ismail ${ }^{c, a}$ \\ ${ }^{a}$ Faculty of Engineering, Tanta University, Egypt. \\ ${ }^{b}$ Faculty of Engineering, BAU, Lebanon \\ ${ }^{c}$ Faculty of Petroleum and mining Engineering, Suez University, Egypt.
}

\begin{abstract}
The present experimental work aims to enhance the daily productivity of solar stills. A stepped pyramidal still with three trays was fabricated and tested under Tanta conditions, Egypt in September 2016. The still was tested with the brine feed being uninterrupted in one experiment, and with intermittent brine supply in another experiment. For continuous brine supply, the accumulated distillate was 4.95 L. For intermittent brine supply, the accumulated distillate was 4.6 L. Per unit total area, the average daily distillate water productivity is 5.5 and $5.11 \mathrm{~L} / \mathrm{m}^{2}$ for the continuous and the intermittent feed stills, respectively. In the two ways, the still yielded a greater productivity than that of conventional pyramid solar still which is 4.4 $\mathrm{L} / \mathrm{m}^{2}$.
\end{abstract}

\section{Introduction}

Along with the growth of population, the demand for fresh water is increasing in parallel. Unfortunately, the resources of fresh water on the earth are being over depleted, thus the call for making the abundant saline water suitable for domestic, irrigation and especially for drinking purposes is rising. One of the solutions on the table is solar desalination. Taking advantage of the renewable solar radiation, the solar desalination has been attractive for so long, and much research is being done in this area.

Solar still is one of the solutions that have been thought to be reliable and cost effective. Solar stills take advantage of two resources available abundantly almost everywhere on the earth, saline water and the sun. The principle of solar stills depends mainly on evaporating the brackish or saline water kept in the basin and condensing the vapor later when getting with the glass cover. The condensed droplets are being collected in a separate reservoir as distillate [1]. Conventional solar still is simple in construction as it consists of a basin covered with a tilted transparent cover. Unfortunately, conventional solar still has low capacity due to loss of latent heat of condensation to surrounding and the difficulty in increasing the evaporation temperature of water [2]. So, great efforts have been done to increase the productivity of distillate by investigating the development of some design parameters such as the shape, the material used and the depth of water in the basin. 
Solar stills may be classified as either passive or active according to the source of the thermal energy used to evaporate the water. Both of passive and active stills are further classified as single effect (SE) and multi effect (ME) still according to the number of glazing layers.

In passive solar stills, the only used source of thermal energy is the direct solar radiation. Its simplest design is SE passive solar still having conventional basin of rectangular in top view and trapezoidal in front view. However, different shapes of passive solar stills were investigated with the aim of collecting more solar radiations such as triangular stills, tubular stills, hemispherical stills, vertical stills and pyramidal still [3]. In a multiple-slope solar still, the optimum tilt angle for the cover was believed to be $23^{\circ}$ [4]. To overcome the problem of heat losses to the surrounding, ME solar still is used as the multi-glass layers utilize more heat and the efficiency is enhanced.

In active solar stills, other sources of energy, rather than solar radiation, acquire much more increasing in the water temperature and hence the evaporation is enhanced. The inclined solar still was investigated. It is inclined to the horizontal surface with the aim of producing larger productivity through acquiring long flow path, long retention time and high rate of evaporation [3]. It can be mainly classified as wick type and basin type inclined solar stills. In wick type, the saline water is slowly fed through a porous, radiation-absorbing pad (the wick) which can be made of cotton, jute, metal pieces, stones etc. [5]. Its simplest design is the single wick still [6]. Due to its small heat capacity, the time required to evaporate the water is decreased, and the productivity in turn, can be enhanced by $16-50 \%$ as compared to basin solar still [7]. Other designs of wick inclined still have been investigated [3]. One of them is that investigated by Minasian et al. [8] which consists of small conventional solar still integrated with a wick-type solar still in such a manner that hot water leaving the wick-type still would directly feed basin-type still. The productivity of this still is $8.477 \mathrm{l} / \mathrm{m}^{2} /$ day with efficiency of $78 \%$ as compared to a sole wick type with productivity of $5.9701 / \mathrm{m}^{2} /$ day with efficiency of 64 $\%$.

The basin type inclined solar still is a conventional basin still but the whole basin is inclined to enhance the productivity. The angle of inclination depends on the latitude of location and the season. It can be further classified as multi-effect, stepped and cascade solar stills [3]. Abdullah et al. [9] experimented a stepped solar still with cooling the glass cover by flowing a small stream of cold water. The productivity was raised to 5.7 $1 / \mathrm{m}^{2} / \mathrm{d}$ with efficiency of $59 \%$, as compared to a productivity of 3.35 and efficiency of $34 \%$ for the conventional solar still [3]. Moreover, integrating stepped solar still, basin type still, and a mini solar pond has was thought of and put into action by Velmurugan et al. [10]. The productivity was enhanced as a result of preheating the water by the solar pond. Going further, integrating the still furtherly with fins and sponges was observed to raise the productivity to 6.12 with efficiency of $87 \%$. As reviewed in [11], efficiency increases by inclining the basin referred with the sun angle. In addition, thin layer of water flowing over glass cover produces more distillate. Moreover, high efficiency can be achieved by combining wick and basin type still. 
Inclined solar stills have also been designed in various miscellaneous stills. One still is integrated with a sun tracking system to improve the performance of the still [12], another uses a hybrid solar still in which an evacuated solar water heater with the desalination still to preheat the saline water [13]. Further effort was exerted trying to study the effect of forced convection on the productivity of solar stills.

Pyramid solar still is the kind in which top cover has the shape of pyramid. There were basically two shapes covers and basin offered in pyramid solar still: triangular and square pyramid solar still. Hamdan et al. [14] made an experimental and theoretical comparisons on the performance of different multiple basin solar stills, having top cover in shape of squared pyramid. The three stills were constructed using a $0.96 \times 0.96 \mathrm{~m}^{2}$ base area, and the cover of each still is of a pyramid shape and inclined at $45^{\circ}$. They concluded that the distillate output from triple basin solar still was approximately $24 \%$ and $5.8 \%$ greater than that of single basin, double basin respectively. They obtained that the maximum daily efficiencies of triple basin, double basin and single basin solar still were $44 \%, 42 \%$ and $32 \%$ respectively. Kabeel [15] developed a solar still with pyramid shaped cover. He used concave-shaped basin covered with wick to enhance the daily productivity of the simple pyramid solar still. Yield of $4100 \mathrm{ml}$ and $2100 \mathrm{ml}$ per $\mathrm{m}^{2}$ per day was observed for the pyramid shaped concave wick solar still and traditional solar still respectively. He recorded instantaneous efficiency of $45 \%$ whereas average daily efficiency of $30 \%$ for the pyramid solar still. Taamneh and Taamneh [16] studied the effect of forced convection on the daily productivity of a pyramid type solar still with a low power consumption fan integrated with a still with a basin area of $0.95 \mathrm{~m}^{2}$. They found that the productivity was raised by $25 \%$ as compared to free convection solar stills. To evaluate the impact of water amount (expressed as depth of water) in basin on the productivity of single basin square solar still, Al-Hassan and Algarni [17] designed and tested three similar square pyramid solar still. For the experimentations, three different amounts of saline water were used: as 31,61 and 91 in the models 1, 2 and 3 respectively. Average daily output found to be $3.9241 / \mathrm{m}^{2}$ per day, $3.1161 / \mathrm{m}^{2}$ per day and $2.4081 / \mathrm{m}^{2}$ per day for 31,61 and 91 of saline water in basins. From this result, it has been observed that the lower quantity of saline water gives higher productivity. Sathya murthy et al. [18] experimentally studied the parameters affecting the performance of triangular pyramid solar still. They got daily yield of $4.3 \mathrm{~kg} / \mathrm{m}^{3}$ for $2 \mathrm{~cm}$ water depth, $2.3 \mathrm{~kg} / \mathrm{m}^{2}$ for $4 \mathrm{~cm}, 1.2 \mathrm{~kg} / \mathrm{m}^{2}$ for $6 \mathrm{~cm}, 0.9 \mathrm{~kg} / \mathrm{m}^{2}$ for $8 \mathrm{~cm}$ and $0.5 \mathrm{~kg} / \mathrm{m}^{2}$ for $10 \mathrm{~cm}$.

From the previous works, it has been observed that, the pyramid solar still acquires more productivity than the conventional still. So, the study aimed to investigate the pyramid solar still with some configurations either in the geometry or in the water feeding. Stepped trays were used in the pyramid still as a new modification. Besides that, two water feeding methods were considered. The first method is the continuous water feeding while the other is the intermittent feeding. The system has been provided with suitable instrumentations to measure the study parameters like the solar radiation, different temperatures of the still elements (absorbers and glass covers), the inlet water temperature and the productivity. 


\section{Experimental set-up, procedure and instrumentations}

The test-rig is designed and fabricated from commercial available materials. It consists from three main parts (feeding system, solar still system and collecting system). Also, the test-rig is provided with instrumentations to measure the parameters affecting the performance and the productivity (solar radiation and temperatures at various positions). The design configurations, fabrication, construction of the tested unit, the instrumentation and measuring techniques are described in the following sections.

\subsection{Experimental set-up description}

Fig. 1 illustrates a photograph of the present work test-rig. The first part of the test-rig is the solar still system, which consists of two main components; glass covers, absorber and the stepped trays. Four glass covers are mounted stably on the structural frame. Each cover is inclined to the horizontal by an angle of $72^{\circ}$ to attain the most reliable conjunction with the plates. The dimensions of each glass cover and corresponding frame $1 \mathrm{~m} \times 1.5 \mathrm{~m}$ with a thickness of $5 \mathrm{~mm}$. In addition, three trays are mounted on a vertical rod, on at the base (absorber) and the others at two different heights, as shown in Fig. 2. The bottom tray is insulated as it is considered as absorber plate while the other plates, upper and middle, are not insulated as they are just considered as stepped trays. This rode acts as supporting to the horizontal trays and partially supporting the weight of the inclined glass covers. The areas of the absorber and the two trays vary from lower plate to the upper plate according to the pyramidal sectional area at the absorber height. The area of absorber is $0.9 \mathrm{~m}^{2}$ while areas of the trays are 0.36 and $0.11 \mathrm{~m}^{2}$ at the middle and the upper, respectively. So, the total surface area is $1.37 \mathrm{~m}^{2}$. The vertical distance between each subsequent two plates is about $35 \mathrm{~cm}$. The solar still system is well-sealed to avoid the leakage of water vapor to the outside. The second part of the unit is the distilled water collecting system, Fig. 3. It consists of four small tray channels inclined and attached to each glass cover. Each one is inclined to help the collecting of the condensed water to the collecting hose attached at the end of each deflector. Each hose is connected to a calibrated collecting tank.

Finally, the feeding saline water system, Fig. 4, through which water is fed to the apparatus through three hoses with $1 \mathrm{~cm}$ diameter each. One end of each hose is connected to a separate, manually-operated valves. These valves are mounted on a highly elevated water tank. The feeding system has two different configurations, one is for the continuous brine supply and the other is for the intermittent brine supply. K-type thermocouples are used for measuring the glass covers, inlet saline water, brine temperature and the absorber surfaces. . Thermocouples are fixed on the surface of the absorbers and at the upper side of glass covers. Fig. 5 Shows the locations of the thermocouples. 


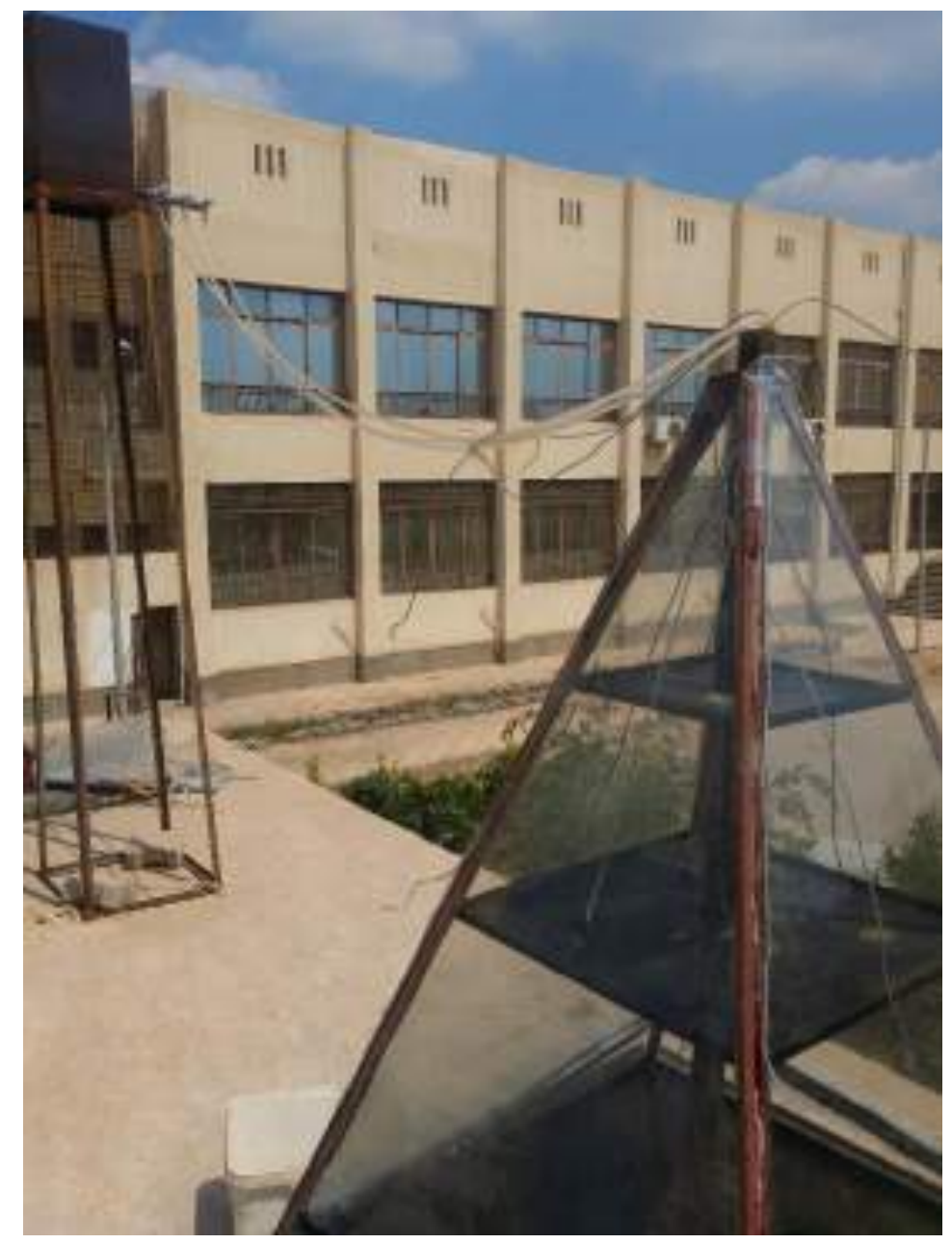

Fig. 1 A photograph of test-rig

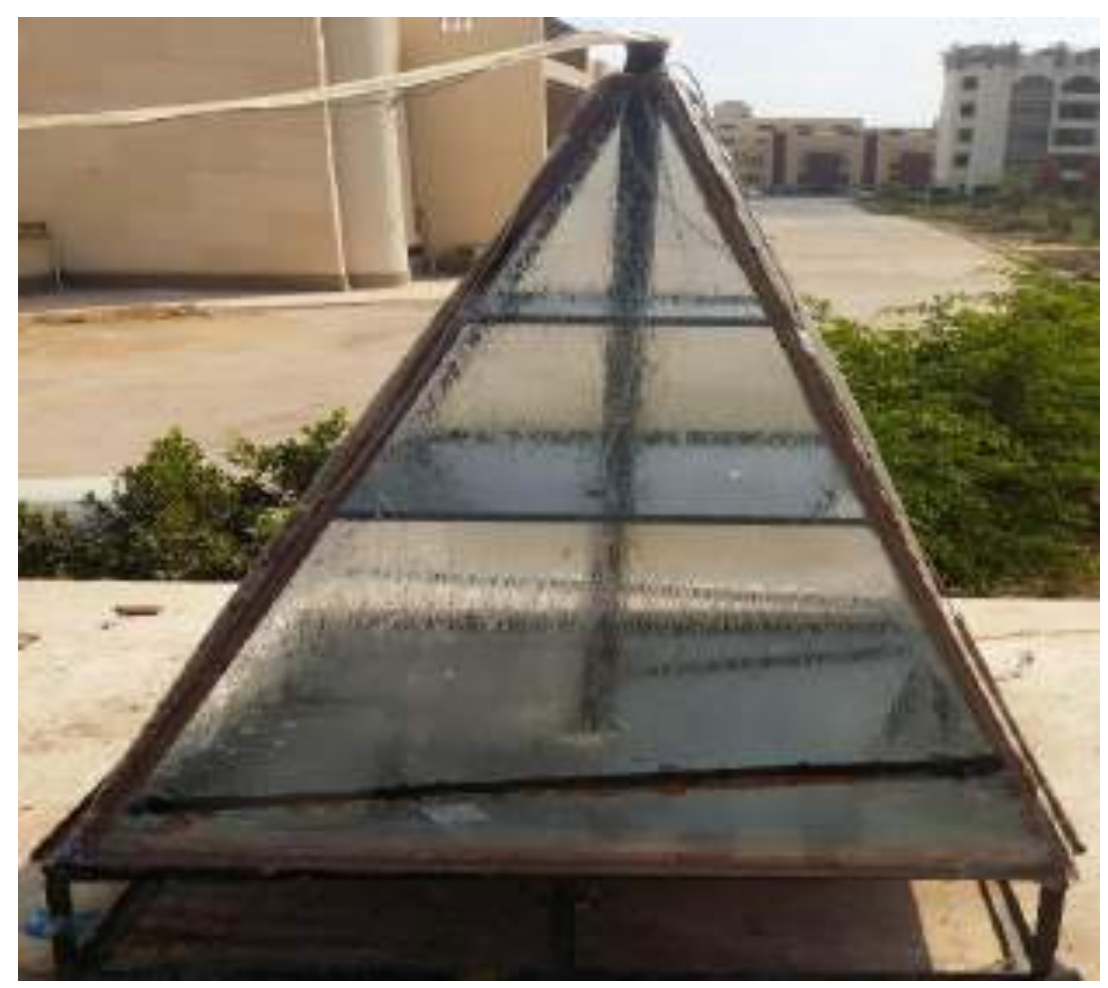

Fig. 2 A photograph of the absorber plates. 


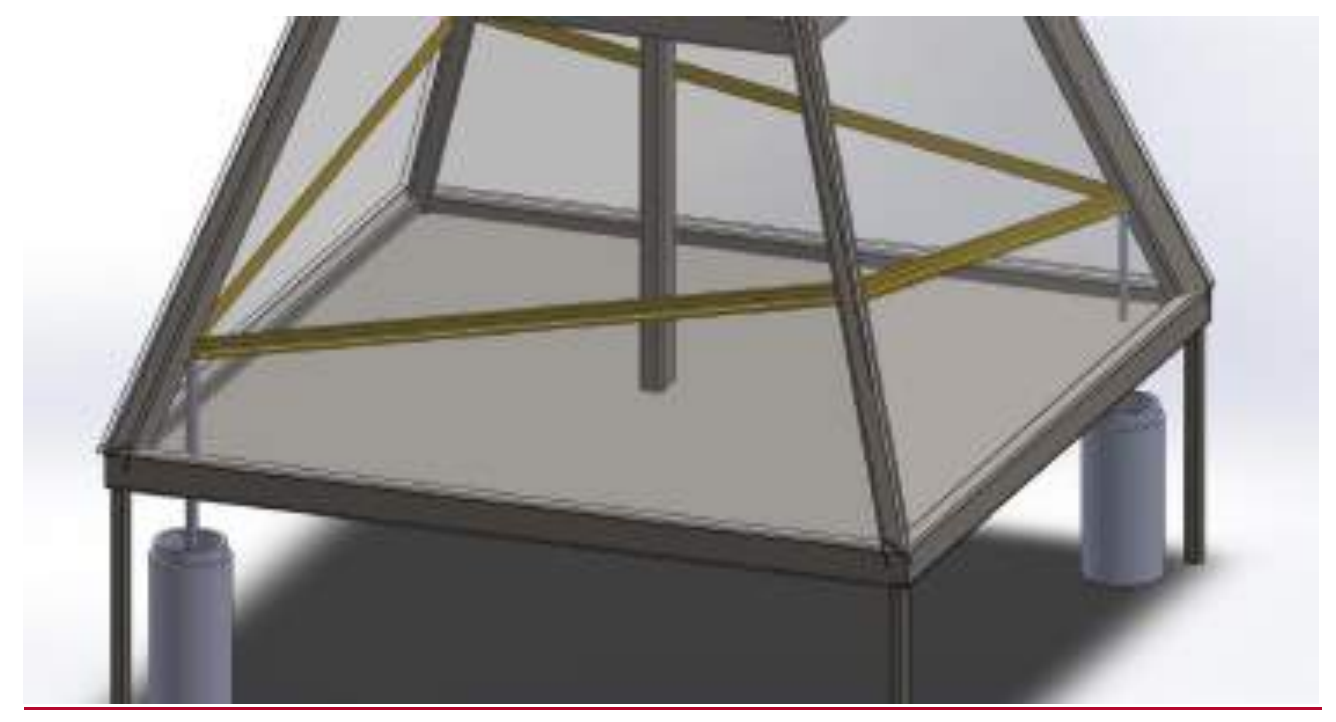

Fig. 3 A schematic diagram of the collecting system

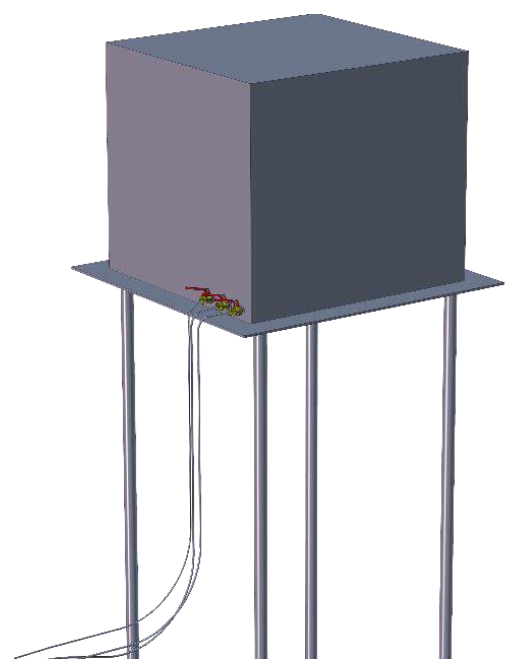

Fig. 4 A schematic diagram of the feeding system

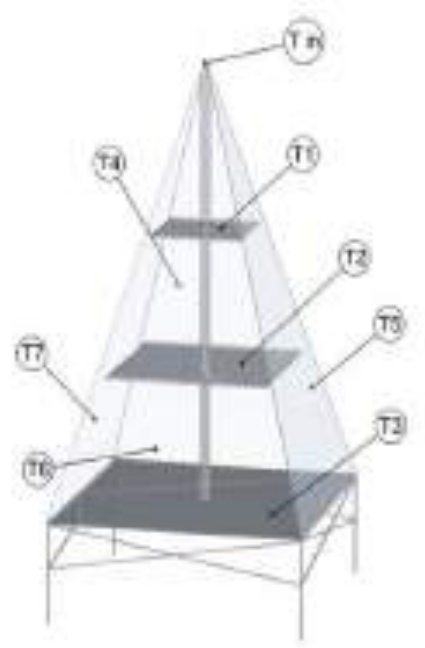

\begin{tabular}{|c|c|}
\hline symbol & Temperafure of . \\
\hline$\pi$ & Liper atwother plals \\
\hline 12 & Shalle alsuba plak \\
\hline 13 & Lexerdenter flote \\
\hline 14 & Nortim cower \\
\hline TS & Fades amet \\
\hline If: & Sculbeni cevar \\
\hline 17 & Weiters sure \\
\hline tí & títs steare \\
\hline
\end{tabular}


Fig. 5 The positions of the thermocouples

\subsection{Experimental procedure and instrumentations}

Stepped pyramidal solar still is experimentally tested in outdoor environment. The experiments were conducted in two different ways. The first way is intermittent brine supply, which depends on attaining an almost constant water level over the trays through manually adjustable valves at the hoses inlets. In the second way, the valves are always opened and the hoses are plugged at the end with some filler. Near these ends though, a tiny hole is cut in each hose acting as a choke to restrict the flow rate. Water delicately flows out of these holes spreading over the horizontal trays continuously compensating for the distilled water. The Experiments were conducted at the Faculty of Engineering, Tanta University, Egypt and carried out from 9 am to $5 \mathrm{pm}$ during the period of September 2016. Solar radiation and temperature of absorbers surface, saline water, glass covers, and distilled water are measured every $1 \mathrm{~h}$. The depth of the saline water, $\mathrm{H}=5 \mathrm{~mm}$ in the solar stills is kept constant during the experiment according to the results of [19]. The temperatures were measured using calibrated K-type thermocouples. The readout of the thermocouples is monitored by Avometer. The global incident solar irradiation on the surface is measured by means of data logging solar meter.

\section{Experimental results}

As previously mentioned, the stepped pyramidal solar still has been tested for brine distillation in two different configurations, one with continuous feed ant the other with intermittent feed. The apparatus has been experimentally tested with the feed being intermittent for 3 days in a row, and then tested with continuous feed for other 3 sequential days. The apparatus was under test from 8:30 am to 5:30 pm each day. The temperatures of the four glass-covers as well as the solar intensity falling on each were recorded. The temperatures of both three trays' surface and the inlet brine were also measured. Finally, the volume of the distilled water was measured then the cumulative volume distilled during the whole period of test was calculated. These parameters have been measured each hour during the day of test, and then plotted over the time.

\subsection{Intermittent feeding}

\subsubsection{Solar radiation and temperatures variation}

Fig. 6 shows the solar radiation intensity falling onto the four glass covers with time. The maximum radiation was noticed to be $145,688,777$ and $732 \mathrm{~W} / \mathrm{m}^{2}$, for the northern, southern, eastern and western plates respectively. 


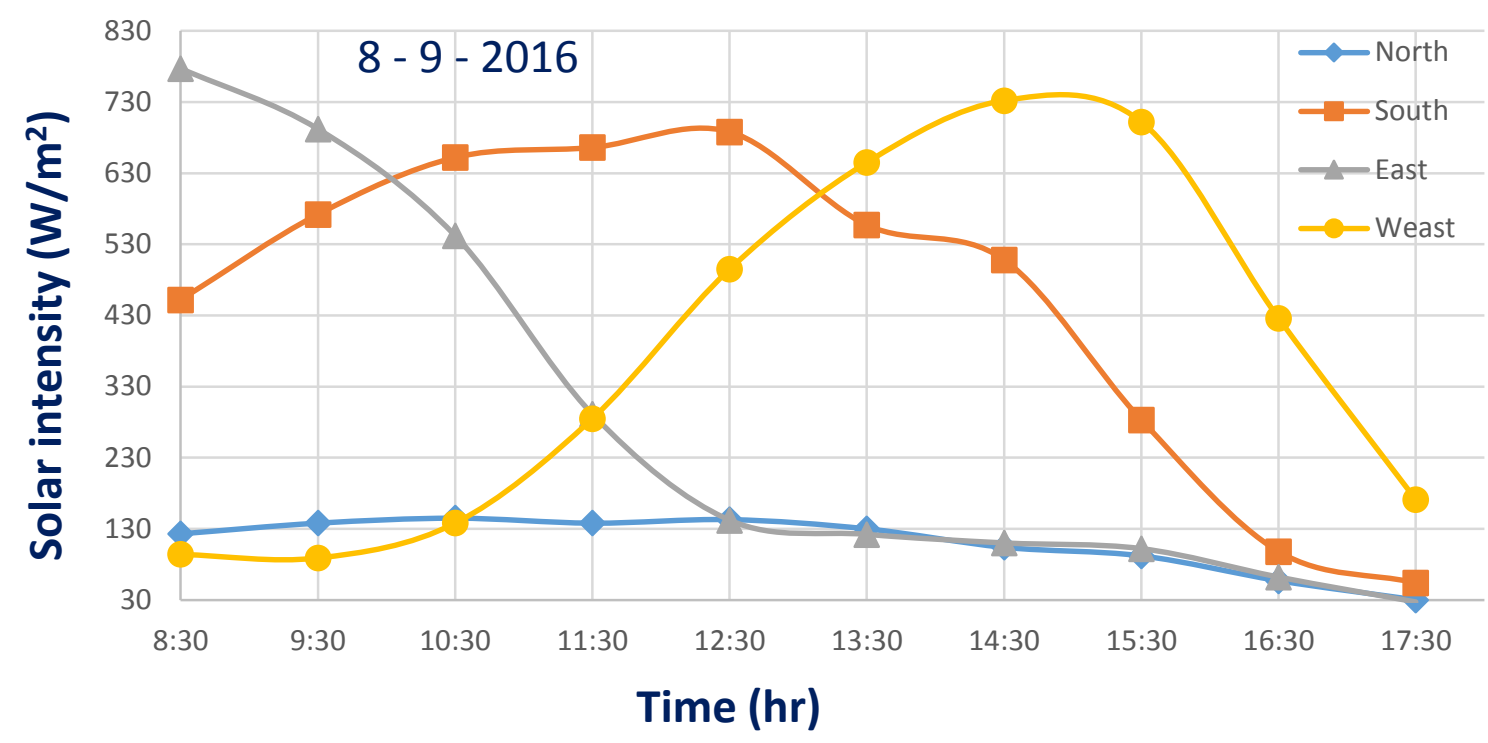

Fig. 6 Solar radiation of the intermittent feeding.

Fig. 7 shows a plot of the temperature of the glass covers with time. The maximum temperature measured was $53,57,54$ and $60^{\circ} \mathrm{C}$, for the northern, southern, eastern and western glass covers respectively. These temperatures were recorded at 13:30 for the northern and eastern covers and at 14:30 for the western and southern covers.

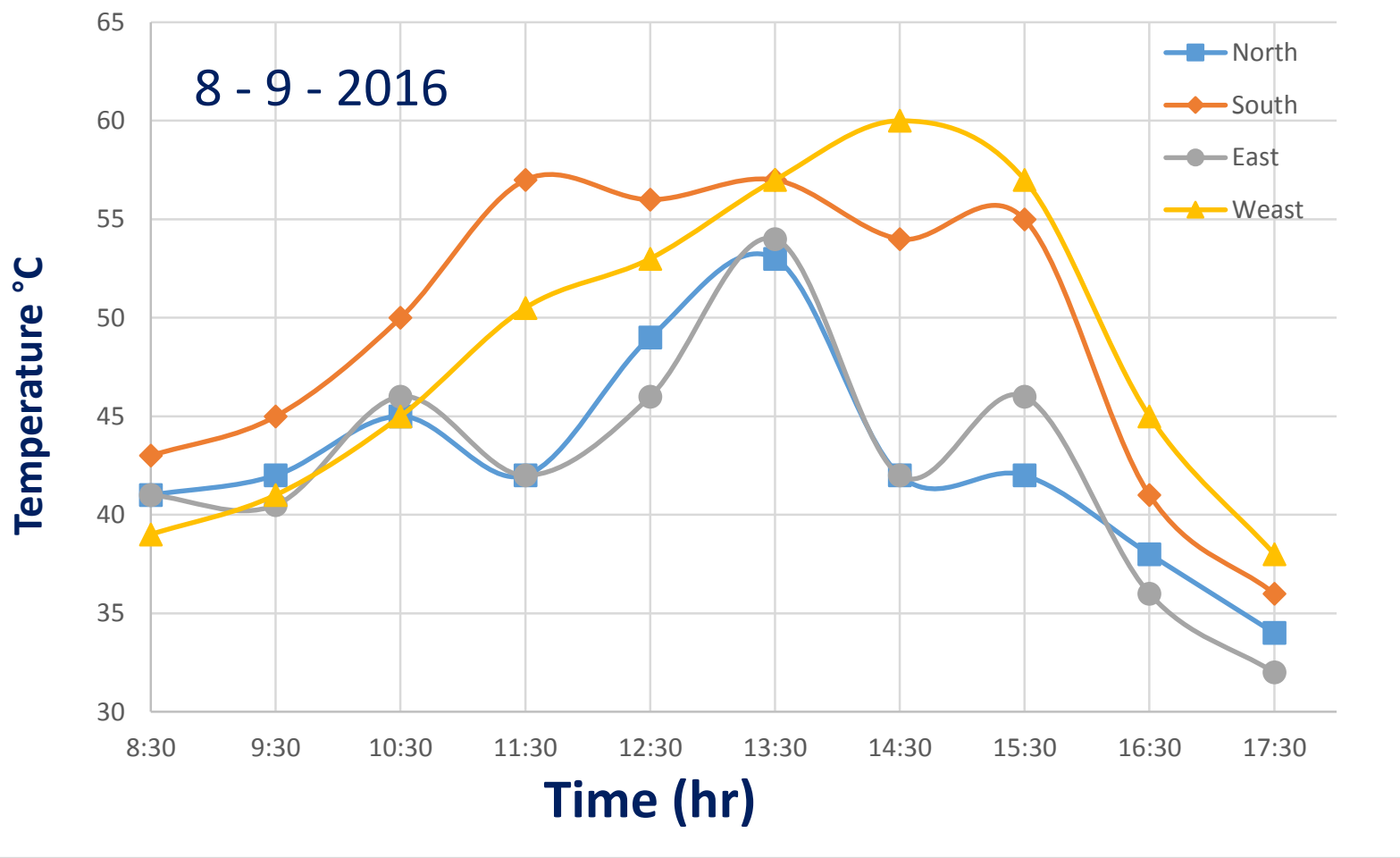

Fig. 7 Temperature variation of the glass covers of the intermittent feeding. 
Fig. 8 shows the temperature of the lower, middle, top absorber plates and that of the inlet stream with time during the second day. The maximum temperatures on the surfaces of bottom, middle and top plates, were 62,65 and $62^{\circ} \mathrm{C}$, respectively. These temperatures were recorded at 13:30, 14:30 and 12:30 respectively. The inlet temperature reached a maximum of $44{ }^{\circ} \mathrm{C}$ at $13: 30$.

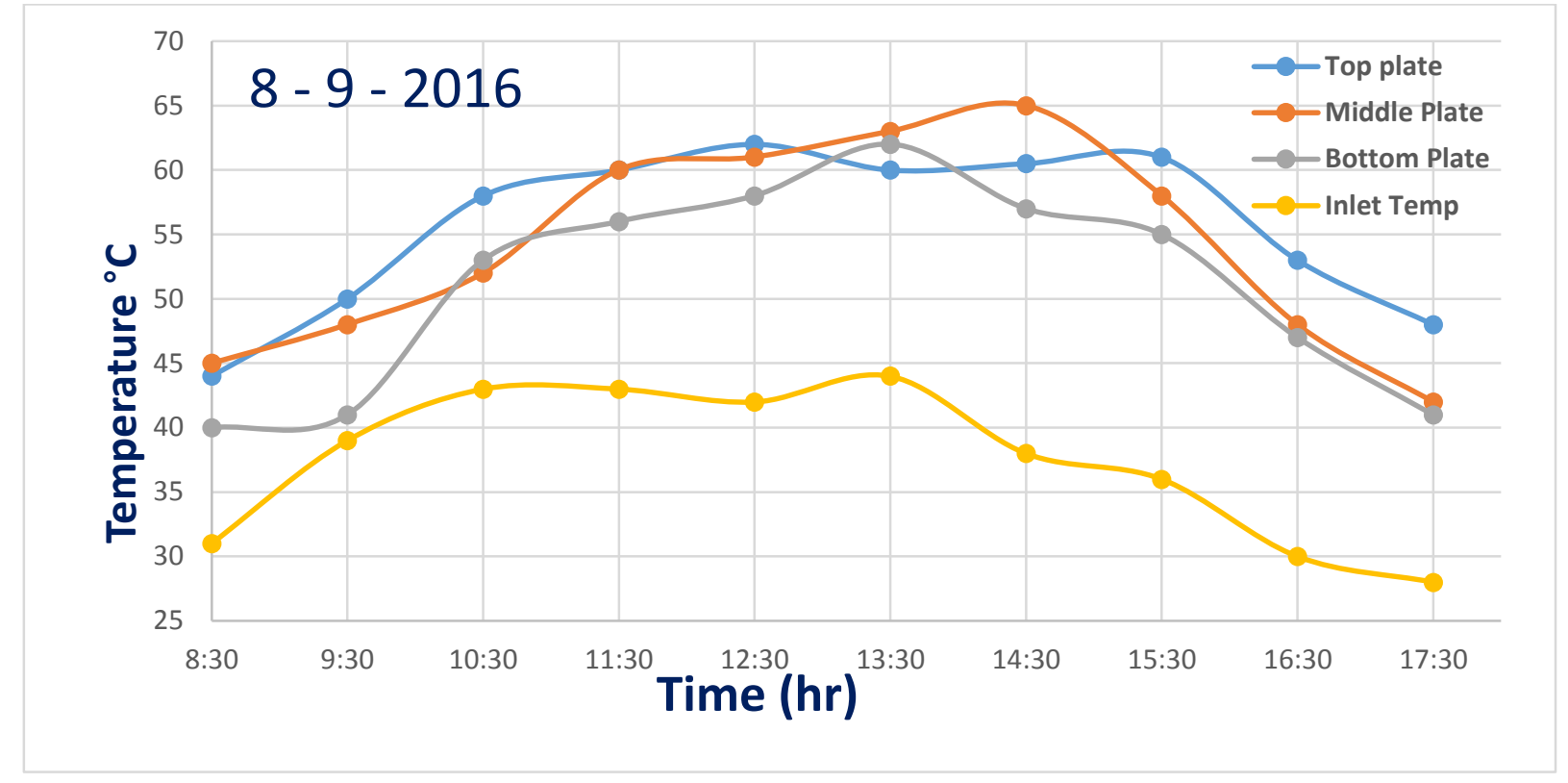

Fig. 8 Temperature variation of the trays' surface of the intermittent feeding.

\subsubsection{Productivity}

Fig. 9 shows the productivity over time, the maximum productivity occurred between 13:30 and 14:30, whereas Fig.10 shows a plot of the accumulative production during that day. The daily accumulative productivity was $5.11 \mathrm{~L} / \mathrm{m}^{2}$. The productivity reached the peak also at 1:30 P.M. of $0.89 \mathrm{~L} / \mathrm{m}^{2}$

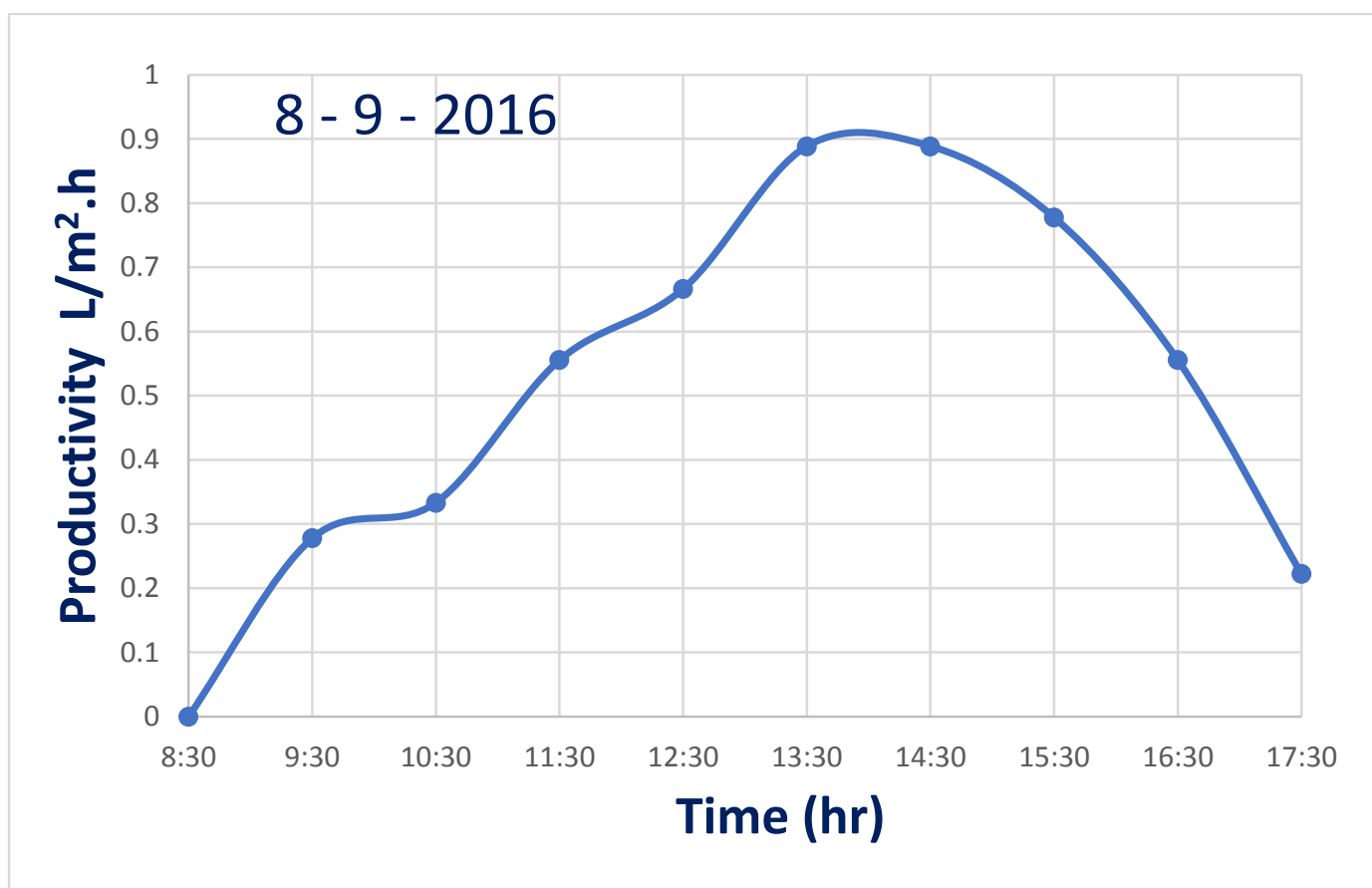


Fig. 9 Hourly productivity of intermittent feeding.

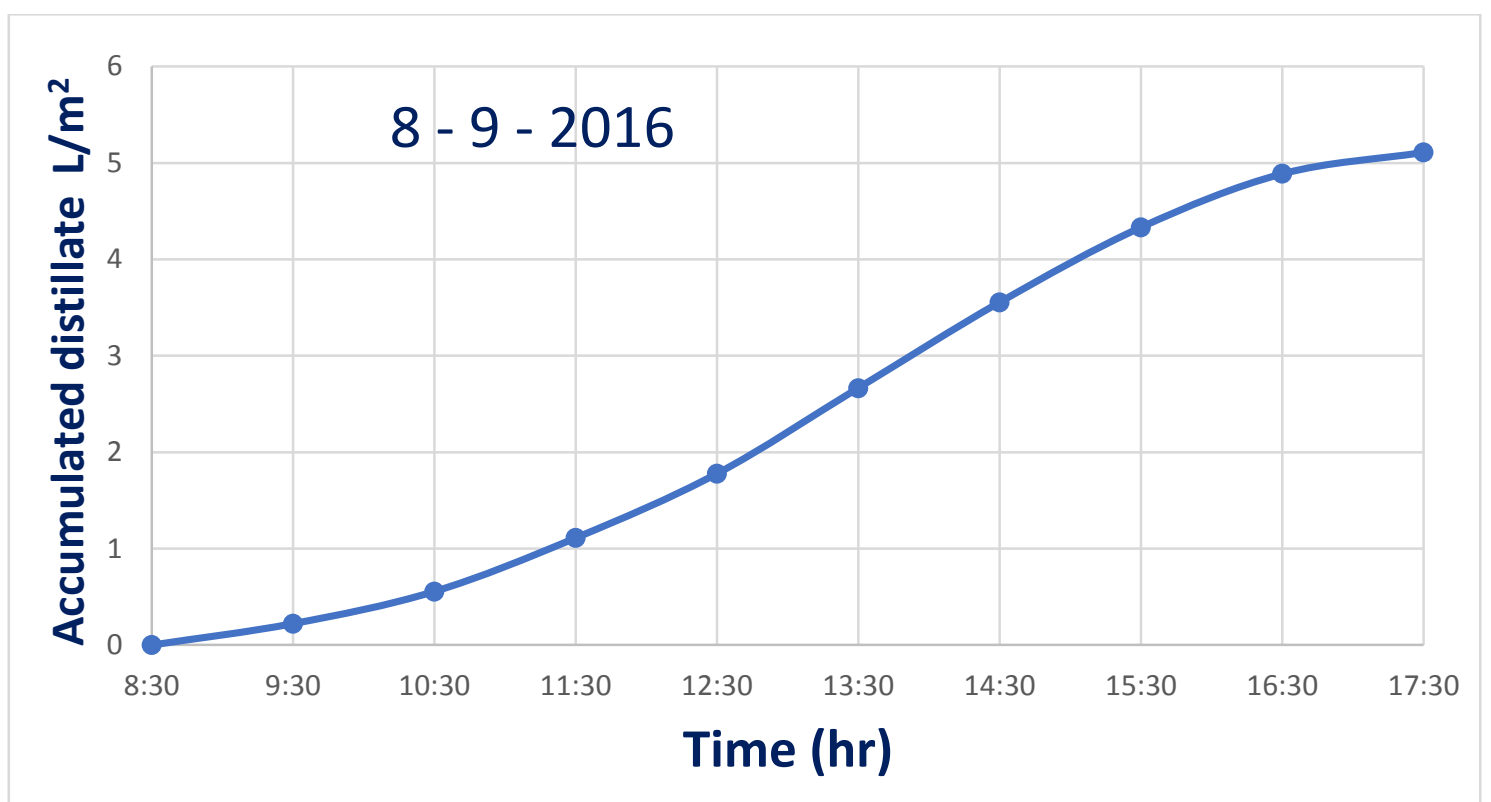

Fig. 10 Accumulative productivity of intermittent feeding.

\subsection{Continuous feeding}

\subsubsection{Solar radiation and temperatures variation}

Fig. 11 shows the solar intensity of the radiation falling onto the four glass covers versus time. The maximum radiation was $150,690,770$ and $735 \mathrm{~W} / \mathrm{m}^{2}$, for the northern, southern, eastern and western plates respectively.

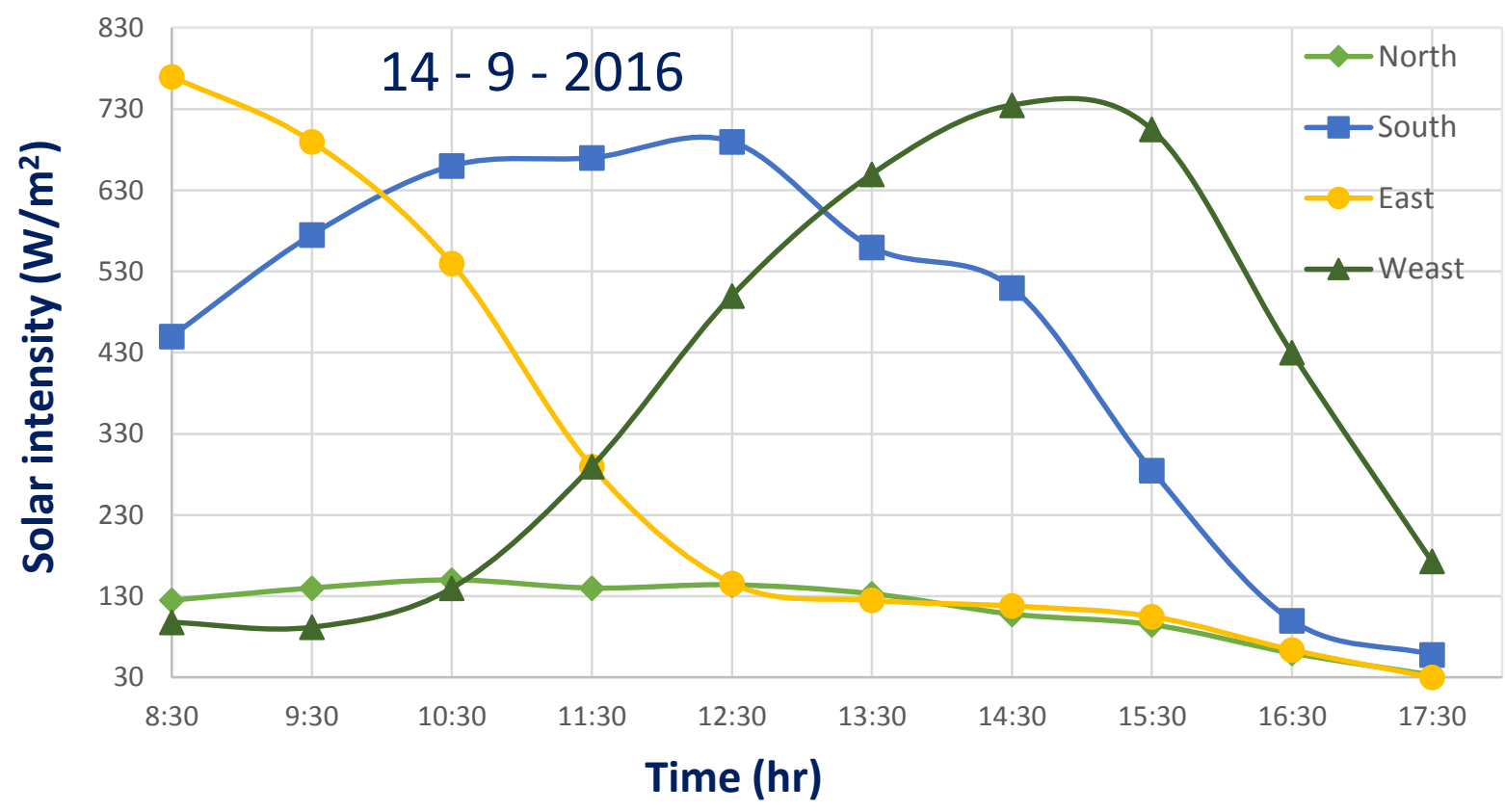

Fig. 11 Solar radiation of the continuous feeding. 
Fig. 12 shows the temperature of the glass covers versus time. The maximum measured temperatures were 52, 57, 52 and $59{ }^{\circ} \mathrm{C}$, for the northern, southern, eastern and western plates respectively. These temperatures were recorded at 13:30 14:30 13:30 and 14:30, respectively.

Fig. 13 shows the temperature of the lower, middle, top absorber plates and that of the inlet stream versus time. The maximum obtained temperatures on the bottom, middle and top plates, were 60, 62 and 62.5 ${ }^{\circ} \mathrm{C}$, respectively. These temperatures were recorded at 13:30, 14:30 and 14:30 respectively. The inlet temperature reached a maximum of $41.5^{\circ} \mathrm{C}$ at $10: 30$ and a minimum point of $29.5^{\circ} \mathrm{C}$ at $17: 30$.

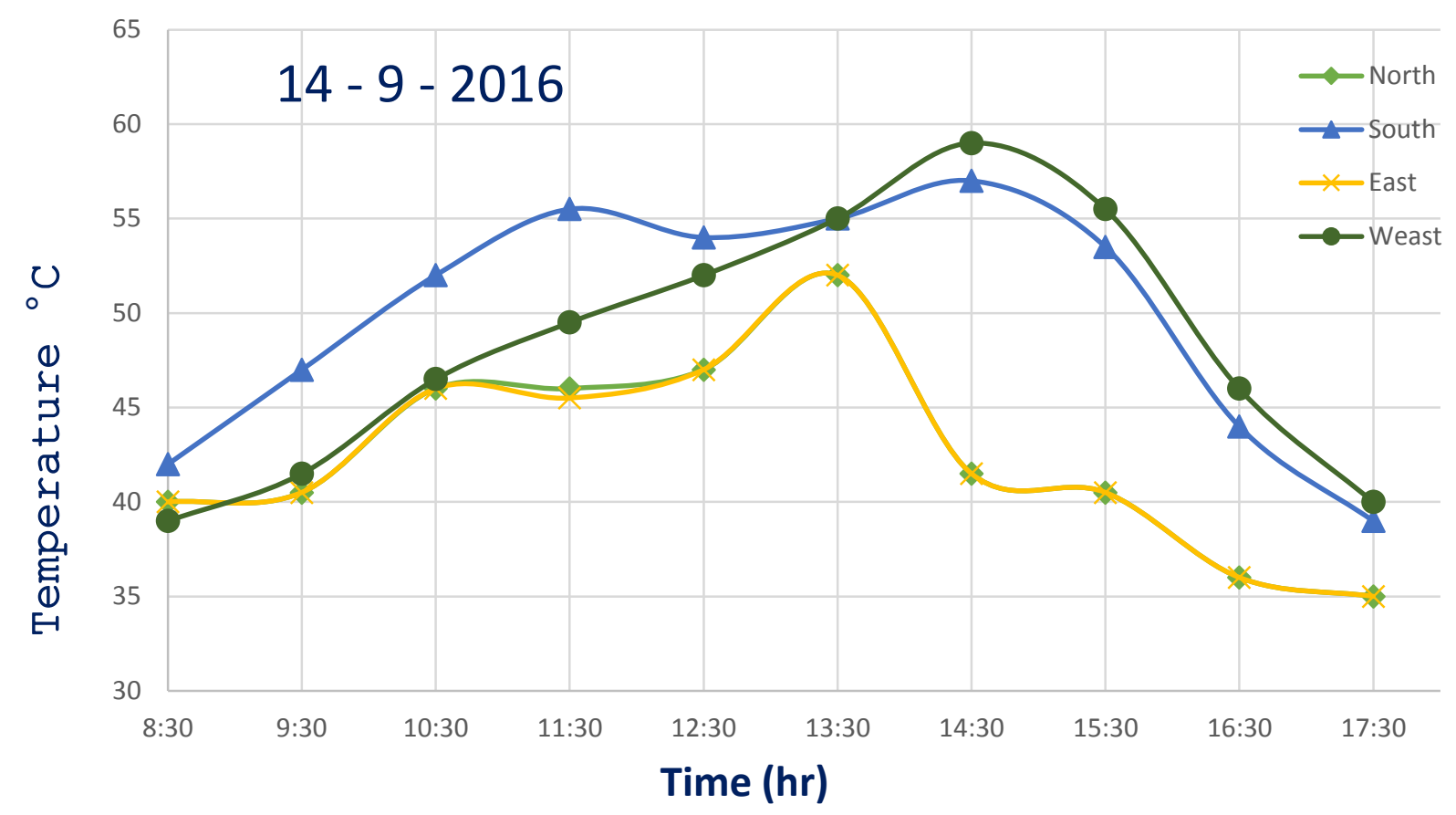

Fig. 12 Temperature variation of the glass covers of the continuous feeding.

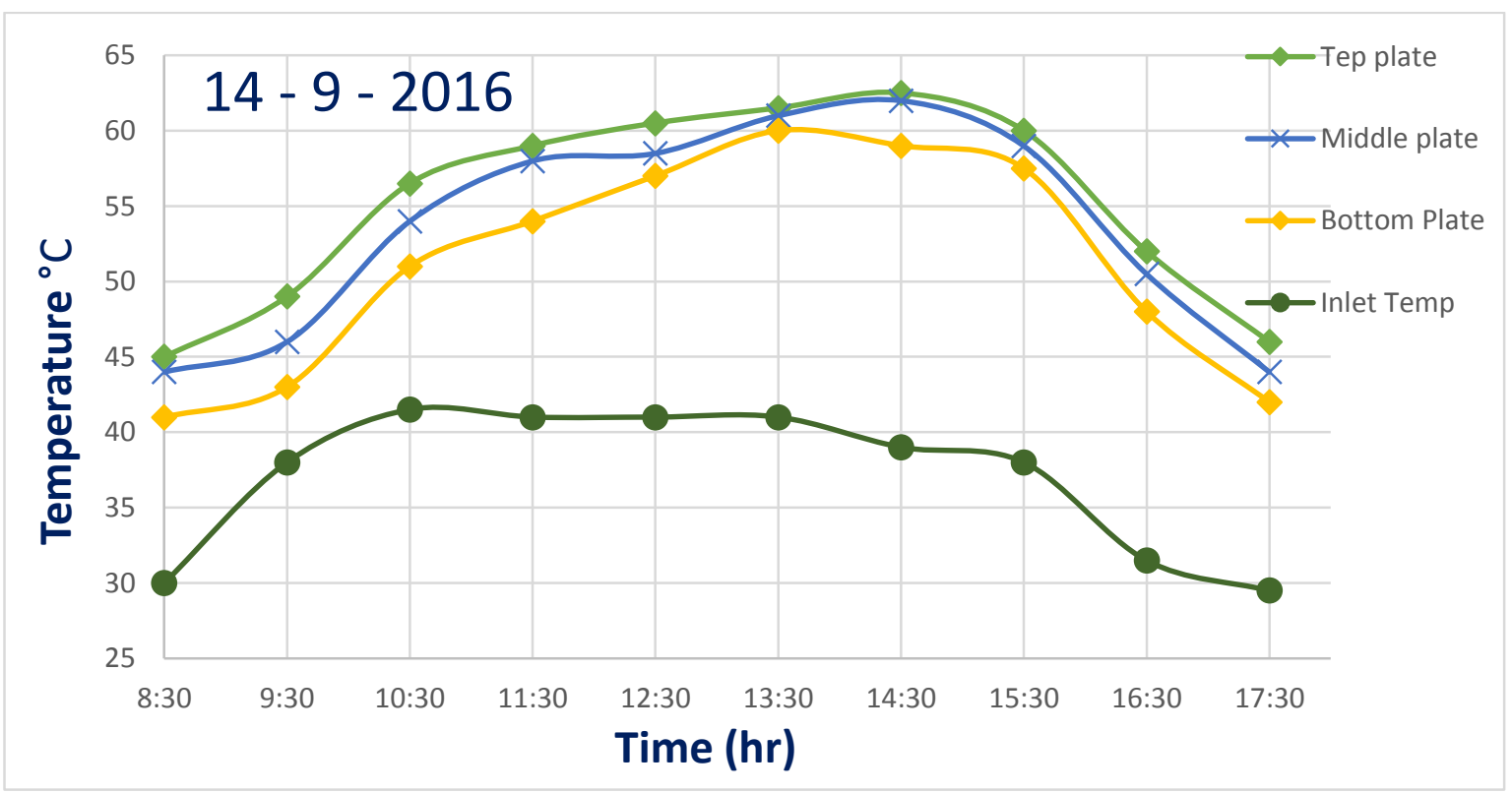


Fig. 13 Temperature variation of the trays' surface of the continuous feeding.

\subsubsection{Productivity}

Fig. 14 shows the productivity over time, the maximum productivity occurred between 13:30 and 14:30, whereas Fig .15 shows a plot of the accumulative production during that day. The still has yielded an accumulative volume of the distilled brine of $5.5 \mathrm{~L} / \mathrm{m}^{2}$. Maximum productivity was acquired at 1:30 pm. The volume distilled from 12:30 to 1:30 was $0.94 \mathrm{~L} / \mathrm{m}^{2}$.

One of the findings is that continuous water feeding is better than intermittent feeding. This is due to the continuous drop of water droplets which works to disturb the water surface and stimulate the surface molecules to evaporate faster than the intermittent feeding state in which the surface is completely stationary.

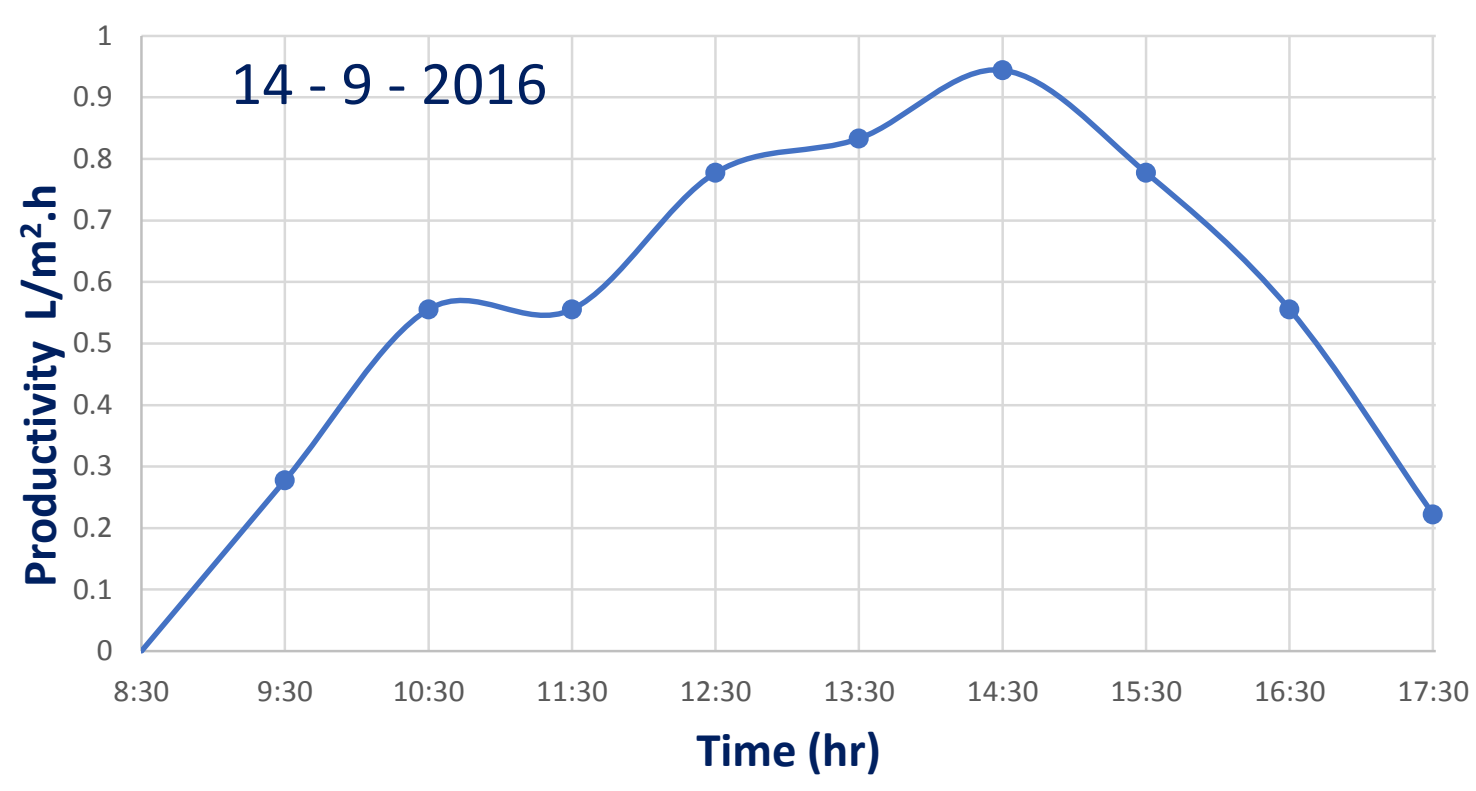

Fig. 14 Hourly productivity of continuous feeding. 


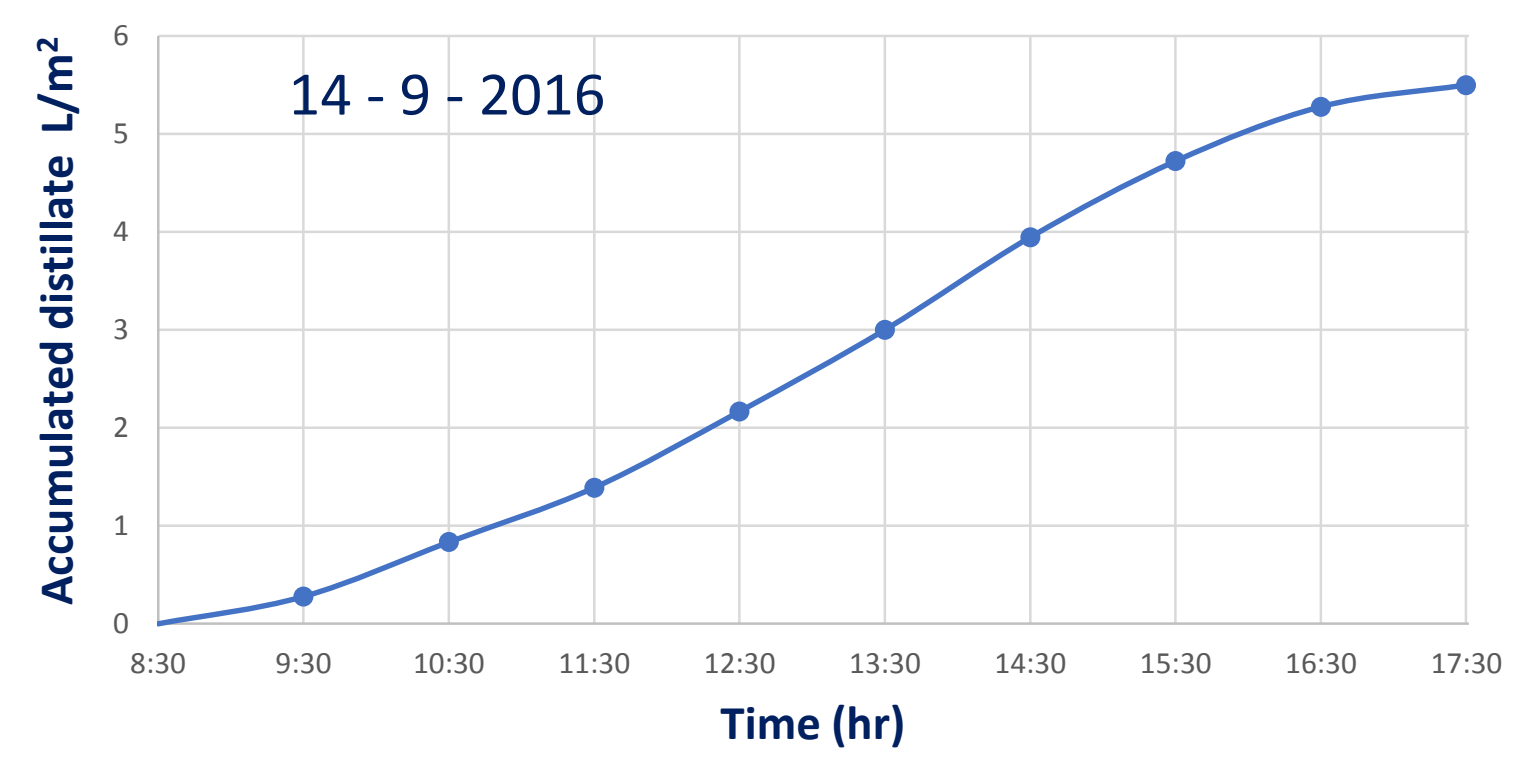

Fig .15 Accumulative productivity of continuous feeding.

The proposed configurations of pyramid solar still showed an accepted performance compared to some other studied systems as illustrated in Table 1.

Table 1 Comparison between the productivity of the present system and some other systems

\begin{tabular}{|c|c|c|c|c|}
\hline Study & \multicolumn{3}{|c|}{ Design configurations } & $\begin{array}{c}\text { Daily } \\
\text { Productivity } \\
\left(\mathbf{L} / \mathbf{m}^{2}\right)\end{array}$ \\
\hline \multirow{2}{*}{ Present study } & \multirow{2}{*}{\multicolumn{2}{|c|}{$\begin{array}{ll}\text { - } & \text { Pyramid solar still } \\
\text { - } & \text { With two stepped trays } \\
\text { - } & \text { Dimensions of basin }=(0.95 \\
& \times 0.95) \mathrm{m}^{2} \\
\text { - } & \text { The glass cover angle is } 72 \\
& \text { degrees to the horizontal }\end{array}$}} & $\begin{array}{l}\text { Intermittent } \\
\text { feeding }\end{array}$ & 5.11 \\
\hline & & & $\begin{array}{l}\text { Continuous } \\
\text { feeding }\end{array}$ & 5.5 \\
\hline Kabeel [15] & \multicolumn{3}{|c|}{$\begin{array}{l}\text { - Pyramid solar still } \\
\text { - The basin is concave } \\
\text { - Dimensions of basin }=(1.2 \times 1.2) \mathrm{m}^{2} \\
\text { - The glass cover angle is } 45 \text { degrees to the } \\
\text { horizontal }\end{array}$} & 4.1 \\
\hline \multirow{2}{*}{$\begin{array}{c}\text { Taamneh and } \\
\text { Taamneh [16] }\end{array}$} & \multirow{2}{*}{ Pyramid solar still } & \multicolumn{2}{|c|}{ With a fan } & 2.99 \\
\hline & & \multicolumn{2}{|c|}{ Without a fan } & 2.485 \\
\hline
\end{tabular}




\begin{tabular}{|c|c|c|c|}
\hline $\begin{array}{c}\text { Arun kumar et al. } \\
{[20]}\end{array}$ & \multicolumn{2}{|c|}{$\begin{array}{l}\text { - } \text { Pyramid solar still } \\
\text { - } \text { Dimensions of basin }=(0.95 \times 0.95) \mathrm{m}^{2}\end{array}$} & 3.3 \\
\hline \multirow{3}{*}{ Kabeel et al. [21] } & \multirow{3}{*}{ 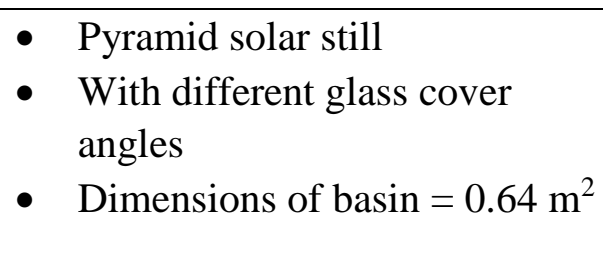 } & $30.47^{\circ}$ & 4.13 \\
\hline & & $40^{\circ}$ & 3.5 \\
\hline & & $50^{\circ}$ & 2.93 \\
\hline
\end{tabular}

\subsection{Pyramid solar still efficiency}

The instantaneous efficiency, $\eta_{\mathrm{i}}$, defined as the ratio between the hourly distillate productivity $\mathrm{m}$ multiplied by the latent heat $\mathrm{h}_{\mathrm{fg}}$ and the summation of solar radiation over the absorber area $\mathrm{A}$.

The daily efficiency, $\eta_{\mathrm{d}}$, is defined as the ratio between the summation of the hourly distillate productivity $\mathrm{m}$ multiplied by the latent heat $\mathrm{h}_{\mathrm{fg}}$ and average solar radiation $\mathrm{I}(\mathrm{t})$ over the absorber area $\mathrm{A}$.

$$
\begin{gathered}
\eta_{i}=\frac{m \times h_{f g}}{\left(\sum I\right) \times A} \\
\eta_{d}=\frac{\sum m \times h_{f g}}{I_{\text {avg }} \times A}
\end{gathered}
$$

Assume that, the latent heat $\mathrm{h}_{\mathrm{fg}}=2350 \mathrm{~kJ} / \mathrm{kg}$.

The instantaneous efficiency of pyramid solar still calculated using Eq. (1) during the selected days of intermittent and continuous feeding is shown in Fig. 16. The instantaneous efficiency increases in the morning time until a maximum value at 4:30 pm and then decreases. It can be observed that the efficiency after $3 \mathrm{pm}$ is increasing, while the solar radiation decreases, this may be due the stored energy in the still, which is not considered in calculation, may increase the evaporation process. The efficiency of the pyramid solar still reached about 0.55 for continuous feeding and 0.56 for intermittent feeding. The calculated daily efficiency from Eq. (2) equals 0.37 for continuous feeding and 0.35 for intermittent feeding. 


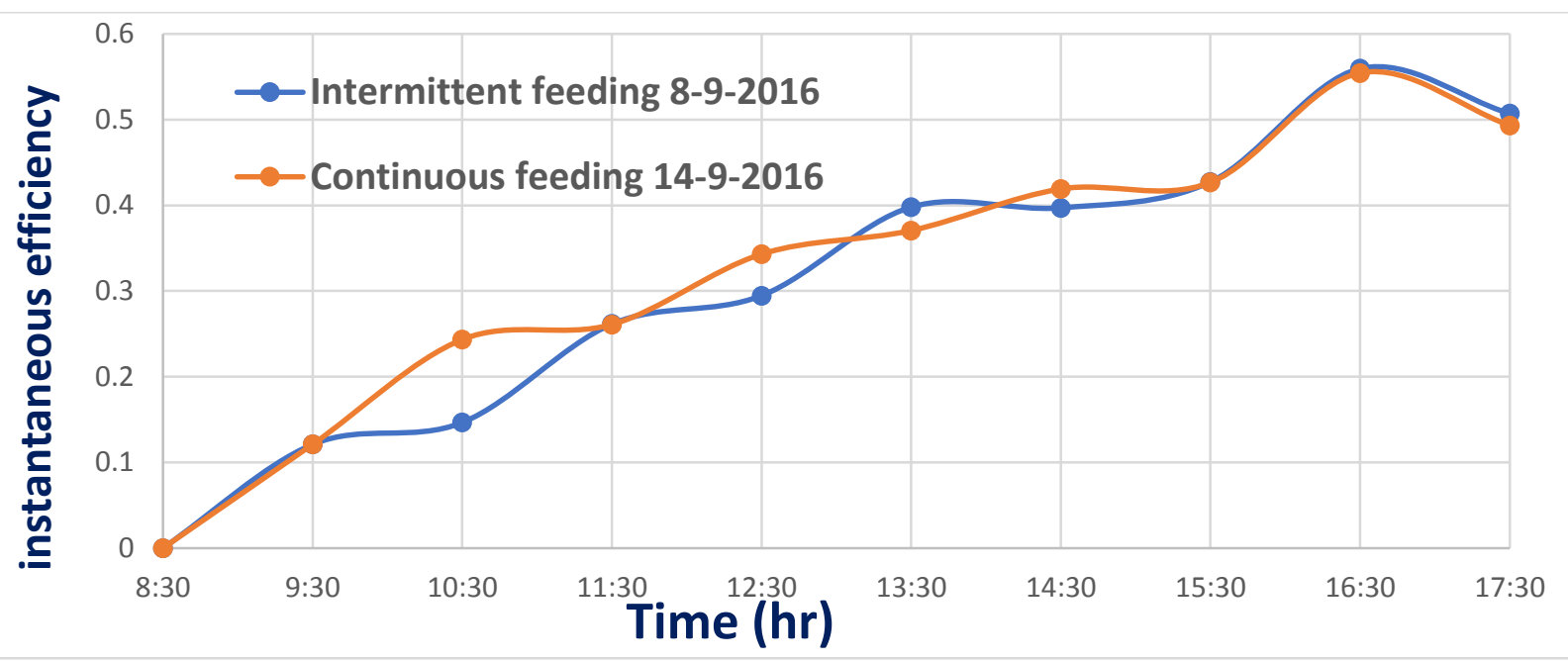

Fig .16 The hourly variation of the instantaneous efficiency for intermittent and continuous feeding

\section{Conclusion}

The current work achieved good enhancement in the daily productivity of solar stills. A stepped pyramidal still with multi trays was fabricated and tested. Two different ways of feeding were tested. The first way is continuous feeding while the second way is intermittent feeding. From the results, it can be concluded that:

- For continuous feeding, the accumulative productivities were $5.5 \mathrm{~L} / \mathrm{m}^{2}$ and the efficiency reached about 0.55 .

- For intermittent feeding, the accumulative productivities were $5.11 \mathrm{~L} / \mathrm{m}^{2}$ and the efficiency reached about 0.56 .

\section{References}

[1] P. K. Abdenacer and S. Nafila, "Impact of temperature difference ( water-solar collector ) on solarstill global efficiency,” Desalination, vol. 209, pp. 298-305, 2007. [2] T. He and L. Yan, "Application of alternative energy integration technology in seawater desalination," Desalination, vol. 249, no. 1, pp. 104-108, 2009.

[3] A. K. Kaviti, A. Yadav, and A. Shukla, "Inclined solar still designs: A review," Renew. Sustain. Energy Rev., vol. 54, pp. 429-451, 2016.

[4] V. S. V. BAPESHWARARAO, U. SINGH, and G. N. TIWARI, "Transient analysis of double basin solar still*," Energy Convers. Manag., vol. 23, no. 2, pp. 83-90, 1983. 
[5] P. Vishwanath Kumar, A. Kumar, O. Prakash, and A. K. Kaviti, "Solar stills system design: A review," Renew. Sustain. Energy Rev., vol. 51, pp. 153-181, 2015.

[6] B. Janarthanan, J. Chandrasekaran, and S. Kumar, "Performance of floating cum tilted-wick type solar still with the effect of water flowing over the glass cover," Desalination, vol. 190, pp. 51-62, 2006.

[7] Z. N. He., "Solar thermal utilization," China Press Univ. Sci. Technol. China, vol. 404, pp. 48-52, 2009.

[8] A. N. MINASIAN and A. A. AL-KARAGHOULI, "AN IMPROVED SOLAR STILL: THE WICKBASIN TYPE,” Energy Convers. Manag., vol. 36, no. 3, pp. 213-217, 1995.

[9] A. S. Abdullah, "Improving the performance of stepped solar still," DES, vol. 319, pp. 60-65, 2013.

[10] V. Velmurugan, S. Pandiarajan, P. Guruparan, L. H. Subramanian, C. D. Prabaharan, and K. Srithar, "Integrated performance of stepped and single basin solar stills with mini solar pond," Desalination, vol. 249, no. 3, pp. 902-909, 2009.

[11] K. Kalidasa Murugavel, P. Anburaj, R. Samuel Hanson, and T. Elango, "Progresses in inclined type solar stills,” Renew. Sustain. Energy Rev., vol. 20, pp. 364-377, 2013.

[12] S. Abdallah, O. Badran, and M. M. Abu-khader, "Performance evaluation of a modified design of a single slope solar still," Desalination, vol. 219, pp. 222-230, 2008.

[13] Z. M. Omara, M. A. Eltawil, and E. A. Elnashar, "A new hybrid desalination system using wicks / solar still and evacuated solar water heater,” DES, vol. 325, pp. 56-64, 2013.

[14] M. A. Hamdan, A. M. Musa, and B. A. Jubran, "Performance of solar still under Jordanian climate," Energy Convers. Manag., vol. 40, no. 5, pp. 495-503, 1999.

[15] A. E. Kabeel, "Performance of solar still with a concave wick evaporation surface," Energy, vol. 34, no. 10, pp. 1504-1509, 2009.

[16] Y. Taamneh and M. M. Taamneh, "Performance of pyramid-shaped solar still: Experimental study," Desalination, vol. 291, pp. 65-68, 2012.

[17] G. A. Al-hassan and S. A. Algarni, "Exploring of Water Distillation by Single Solar Still Basins," vol. 2013, no. March, pp. 57-61, 2013.

[18] R. Sathyamurthy, H. J. Kennady, P. K. Nagarajan, and A. Ahsan, "Factors affecting the performance of triangular pyramid solar still,” Desalination, vol. 344, pp. 383-390, 2014.

[19] A. E. Kabeel, A. Khalil, Z. M. Omara, and M. M. Younes, "Theoretical and experimental parametric 
study of modi fi ed stepped solar still,” DES, vol. 289, pp. 12-20, 2012.

[20] T. Arunkumar, K. Vinothkumar, A. Ahsan, R. Jayaprakash, and S. Kumar, "Experimental Study on Various Solar Still Designs," ISRN Renew. Energy, vol. 2012, pp. 1-10, 2012.

[21] A. E. Kabeel, M. Abdelgaied, and N. Almulla, "Performances of pyramid-shaped solar still with different glass cover angles: Experimental study," IREC 2016 - 7th Int. Renew. Energy Congr., 2016. 